\section{Location and Rootstock Affect Sheepnosing in Grapefruit}

\author{
Bhimanagouda S. Patil ${ }^{1}$ \\ Texas A\&M University-Kingsville Citrus Center, 312 North International \\ Boulevard, Weslaco, TX 78596
}

Additional index words. fruit shape, fruit quality, irrigation, Citrus paradisi, Citrus aurantium, Citrus sinensis $\mathrm{x}$ Poncirus trifoliata

\begin{abstract}
Field studies were conducted for 2 years, at three sites in the Lower Rio Grande Valley of Texas, to evaluate the effects of location, rootstock, and irrigation on sheepnosing (elongation of the apex) of 'Rio Red' grapefruit (Citrus paradisi Macf.). Based on the ratio of equatorial to polar diameter, grapefruit budded on sour orange (Citrus aurantium $\mathbf{L}$.) rootstock grown at Weslaco had a significantly higher percentage of sheepnosed fruits $(63 \%)$ than did fruit grown at Mission $(57 \%)$, while the grove at Bayview produced a negligible percentage of sheepnosed fruit $(4 \%)$. In a second study, 'Rio Red' trees grown on 'Carrizo' rootstock [C. sinensis (L.) Osbeck $x$ Poncirus trifoliata (L.) Raf.] produced a significantly higher percentage of sheepnosed fruit $(59 \%)$ than did those on 'Swingle' $(C$. paradisi $x P$. trifoliata) $(\mathbf{4 8 \%})$. In a third experiment, trees irrigated by microjet had a significantly higher percentage of sheepnosed fruit $(53 \%)$ than did those that were floodirrigated $(43 \%)$. Although sheepnosed fruit had significantly greater peel thickness and a lower juice content, fruit quality was better than that of normal fruit because of a higher soluble solids : titratable acidity ratio. In 1999, the significant irrigation and rootstock effects were less than that due to growing location. Effects of location, rootstock and irrigation varied between years. The interaction between factors and years was mainly due to a lack of low amount of sheepnosing in 1998.
\end{abstract}

Grapefruit grown in the Lower Rio Grande Valley frequently are obovoid, with a high collar around the stem and a depressed button that results in a snout-like appearance, giving rise to the term "sheepnose." The amount of fruit affected varies with year and location. Sheepnosing commonly occurs in grapefruit, but all citrus species may produce fruit with spherical or pyriform shape. 'Rio Red' grapefruit, an excellent cultivar for fresh consumption, attain a favorable oblate shape under humid, subtropical or tropical conditions, but are more spherical under arid conditions (Gibson, 1975). A high proportion of late or off-bloom fruit tends to develop this pronounced neck at the stem end resulting in "sheepnosed" or "stem end tapered" (Wutscher, 1976) or "pyriform" fruit (Gibson, 1975). Sheepnosed fruit often fail to meet market standards. Factors such as tree vigor, temperature and humidity during bloom, fertilizer, irrigation method, rootstock, and water

Received for publication 3 July 2000. Accepted for publication 17 Nov. 2000. This research was funded by the Texas Citrus Producers Board through grant number 461529. I thank Dariusz Swietlik for his valuable comments and assistance during this study; John Fucik, Duane Gardiner, Sangu Angadi, and John da Graca for their critical review of the manuscript; and Daniel Davila, John Watson, and Marc Villalobos for their hard work in helping me with this study. The cost of publishing this paper was defrayed in part by the payment of page charges. Under postal regulations, this paper therefore must be hereby marked advertisement solely to indicate this fact.

${ }^{1}$ Assistant Professor E-mail address: b-patil@ tamu.edu stress have been implicated in sheepnosing of grapefruit (Cohen et al., 1972; Gilfillan and Stevenson, 1976; Wutscher, 1976). Based on observations in Texas over many years, the influence of nutrition and other cultural factors appears to be secondary and depends on their effects on growth rate (John Fucik, personal communication). Studies in South Africa have shown a significant partial correlation between sheepnose incidence and leaf levels of boron, calcium, potassium and nitrogen (Gilfillan and Stevenson, 1976). Cohen and his coworkers (1972), working with grapefruit in Israel, showed that lower winter temperatures resulted in thicker peels the following season. Fruit shape was influenced by both humidity and temperature, but not as consistently as was peel thickness.

Sheepnosing is associated with thick rinds and puffiness of the fruit. Fruits are elongated at the pedicel and tend to have thick, rough peels. Gibson (1975), working in Arizona, showed that flowers that produced sheepnosed grapefruit developed wider and longer pistils than normal flowers; this difference was maintained and protracted until fruit maturity. Sheepnosing was induced by low night temperatures in growth chambers (Wutchser, 1976). Experimental conditions did not permit the separation of effects of temperature and humidity; however, the authors reported that the peel was consistently thicker when the difference between day and night temperatures was large, and therefore the peel was thicker in inland than in coastal areas (Nauer et al., 1975; Wutscher, 1976). Young, vigorous nucellar seedlings are more likely to bear sheepnosed fruit; the problem is more prevalent inland than in coastal growing areas (Soost et al., 1965). In Arizona, sheepnosing is more severe in Yuma Mesa, a desert location characterized by wide diurnal temperature fluctuations, than in other locations (Reuther, 1973).

The problem of sheepnosing is serious and in some years may result in fresh fruit packouts of less than 30\% (John Fucik, personal communication). While the abnormalities in fruit shape and peel thickness usually appear together, each of these characteristics is influenced independently by climatic factors (Cohen et al., 1972; Reuther 1973). The great variability in the shape of citrus fruit from year to year suggests that shape is related variations in climate.

Very little information is available with respect to influence of rootstock on fruit shape or sheepnosing. One study showed that citrus fruit peel becomes thicker and rougher when the cultivar is budded on sour orange rather than sweet lime rootstock (Erner et al., 1975).

Field experiments were conducted for 2 years to determine the effects of location, irrigation, and rootstock on sheepnosing of grapefruit in Texas. Fruit quality of sheepnosed fruit was compared with that of normal fruit.

\section{Materials and Methods}

Location. 'Rio Red' grapefruit orchards in three different locations in the Lower Rio Grande Valley \{Bay View (John William's grove), Mission (Sharyland grove) and Weslaco [Texas A\&MUniv.-Kingsville Citrus Center (TAMUK-CC South Farm)] \} were selected for the study. The same trees in each grove were used for measurements in 199798 and 1998-99. In all three groves, the trees budded on sour orange were planted at $4.57 \times$ $7.62 \mathrm{~m}(15 \times 25$ feet $)$ in 1991 and were floodirrigated. Weather data (not presented) for each of these experimental fields were collected from the nearest weather stations. Partial weather data from the two locations is missing because of computer problems experienced by the National Climatic Data Center (NCDC). The three orchards were under the same cultural management practices and received the same fertilization, weed control and pest management during both seasons. The soil in three locations was of Raymondville series (fine, mixed, hyperthermic Vertic Calciustolls), with the surface $90-130 \mathrm{~cm}$ of clay or sandy clay underlain by sandy clay loam.

After setting up standards, sheepnosed and normal fruits were visually categorized by a team of growers and Citrus Center scientists and staff. Based on their groupings, both polar and equatorial diameters of 30 'Rio Red' fruits were measured, and fruits with a ratio of equatorial to polar diameters of 1.00 were considered normal. Furthermore, fruits were categorized as lightly, moderately and severely sheepnosed based on ratios of 1.05, 1.08, and 1.12 , respectively.

Rootstock effects. 'Rio Red' grapefruit trees budded on five rootstocks and planted in 1992 in TAMUK-CC's West Farm at Mission were 
chosen to study rootstock effects on sheepnosing. Trees (30 each) of 'Rio Red' on 'Swingle', 'Carrizo', 'Troyer', sour orange and 'Chinese (Go Tou)' rootstocks were selected for measurements in 1997-98 and 199899. The experiment consists of 10 trees in each of three replications in a randomized block design.

Irrigation. At the TAMUK-CC South Research Farm, a 'Rio Red' grapefruit orchard on sour orange rootstock was selected to examine the effect of irrigation on sheepnosing. The same trees were used in both 1997-98 and 1998-99. The orchard was planted in a randomized block design with 10 trees in each of three replications for comparing flood vs. microjet irrigation. Trees were planted at 4.57 $\times 7.62 \mathrm{~m}(15 \times 25$ feet $)$ in 1991 and received the same cultural practices, fertilization, weed control, and pest management during both seasons, except for the method of irrigation.

Fruit measurements. Three replications of 10 trees each were selected from each category of sheepnosed fruit. Fruit were harvested in March of both years, and run through the TAMUK-CC packing line to determine the number of fruit in each of the following commercial size categories: 63 and smaller, 56, 48, 40, 36, and 32 and larger (number indicates number of fruit/box). Fruit diameters for sizes $>56,56,48,40,36$, and $<32$ were $>8.41,8.41-9.21,9.21-9.53,9.53-10$, $10-10.64$, and $\leq 10.64 \mathrm{~cm}$., respectively. In each size class, fruits were manually rated for sheepnosing based on the ratio of equatorial to polar diameter. The percentages of sheepnosed and normal fruit were calculated based on the total number of fruit per tree. The percentage of lightly, moderately, and severely sheepnosed fruit among total sheepnosed fruit were also determined.

Fruit quality. Sheepnosed fruit often fail to meet consumer's quality demands for the fresh market. In addition to reduced aesthetic value, the edible portions (pulp volume, juice percentage) are reduced relative to normal fruit (Erner et al., 1975). At the TAMUK-CC South Research Farm, samples of 30 fruit were collected from each of three replications of severely and moderately sheepnosed fruit, as well as normal fruit from the same tree, in both years. Fruit were evaluated for soluble solids concentration (SSC) and titratable acidity (TA), as described by Shellie et al. (1993), using a temperature compensated refractometer (Bausch and Lomb, Rochester, N.Y.), and titrator (model DL21; Mettler Toledo, Columbus, Ohio), respectively. Firmness (Newtons) was measured in four places on the fruit surface using an Accu Force Cadet Force Gage (Wagner Instruments, Greenwich, Conn.). Peel thickness (mm) was also measured. Percentage of juice was determined by dividing the weight of extracted juice by the fruit weight and multiplying by 100 .

Statistical analysis. The experimental design was a split-plot, with year as main plot and locations, rootstocks, and irrigation methods as sub-plots in each experiment. Data from both years were pooled in all the experiments after testing the homogeneity of error variance using Bartlett's test, and analyzed using a split-plot design (genaral linear method procedures, SAS Institute, Cary, N.C.). Fisher's protected LSD was used for mean separation.

\section{Results and Discussion}

Location. Location has a strong influence on fruit shape. Regardless of size, severity of sheepnosing was significantly higher at Weslaco (23.8\%) than at Mission (13.2\%), while fruit grown in Bayview had no severely sheepnosed fruits (Tables 1 and 2). Considering all sizes and locations, the percentage of severely and moderately sheepnosed fruit was significantly lower and the percentage of normal fruits significantly higher in 1998 than in 1999 (Tables 1 and 2). Location $\times$ year interaction was more pronounced when sheepnosing was severe (Table 2). For example, the percentages of lightly sheepnosed fruit at Weslaco differed much less between years than did the percentages of severely sheepnosed fruit. However, in Bayview, differences between years were not significant regardless of severity. As noted above, some weather data for two experimental locations was unavailable. Based on the available data, our results indicate that, between April and October, mean daily maximum temperature was significantly lower, and relative humidity higher at Bayview than at Mission and Weslaco. In general, the

Table 1. Location and year effects on the percentages of sheepnosed and normal fruit in different commercial sizes of 'Rio Red' grapefruit. ${ }^{\mathrm{Z}}$

\begin{tabular}{|c|c|c|c|c|c|c|c|c|}
\hline & \multicolumn{8}{|c|}{ Size (fruits/box) } \\
\hline & $>56$ & 56 & 48 & 40 & 35 & 32 & $<32$ & All sizes \\
\hline \multicolumn{9}{|c|}{ Severely sheepnosed (Equatorial : Polar diameter $=1.12$ ) } \\
\hline Location & & & & & & & & \\
\hline Weslaco & $0.1 \mathrm{a}^{\mathrm{y}}$ & $0.2 \mathrm{ab}$ & $0.4 \mathrm{a}$ & $0.8 \mathrm{~b}$ & $2.3 \mathrm{a}$ & $2.3 \mathrm{a}$ & $17.7 \mathrm{a}$ & $23.8 \mathrm{a}$ \\
\hline Mission & $0.0 \mathrm{~b}$ & $0.2 \mathrm{a}$ & $0.7 \mathrm{a}$ & $1.0 \mathrm{a}$ & $3.1 \mathrm{a}$ & $1.6 \mathrm{a}$ & $06.6 \mathrm{~b}$ & $13.2 \mathrm{~b}$ \\
\hline Bayview & $0.0 \mathrm{~b}$ & $0.0 \mathrm{~b}$ & $0.0 \mathrm{~b}$ & $0.0 \mathrm{~b}$ & $0.0 \mathrm{~b}$ & $0.0 \mathrm{~b}$ & $00.0 \mathrm{c}$ & $00.0 \mathrm{c}$ \\
\hline \multicolumn{9}{|l|}{ Year } \\
\hline 1998 & $0.0 \mathrm{a}$ & $0.1 \mathrm{a}$ & $0.3 \mathrm{a}$ & $0.5 \mathrm{a}$ & $1.8 \mathrm{a}$ & $1.0 \mathrm{a}$ & $4.3 \mathrm{~b}$ & $7.8 \mathrm{~b}$ \\
\hline 1999 & $0.1 \mathrm{a}$ & $0.2 \mathrm{a}$ & $0.5 \mathrm{a}$ & $0.7 \mathrm{a}$ & $1.8 \mathrm{a}$ & $1.7 \mathrm{a}$ & $12.0 \mathrm{a}$ & $16.8 \mathrm{a}$ \\
\hline \multicolumn{9}{|c|}{ Moderately sheepnosed (Equatorial : Polar diameter $=1.08$ ) } \\
\hline Location & & & & & & & & \\
\hline Weslaco & $0.1 \mathrm{a}$ & $0.5 \mathrm{~b}$ & $0.8 \mathrm{~b}$ & $1.5 \mathrm{~b}$ & $3.9 \mathrm{a}$ & $2.2 \mathrm{a}$ & $9.6 \mathrm{a}$ & $18.5 \mathrm{a}$ \\
\hline Mission & $0.1 \mathrm{a}$ & $1.6 \mathrm{a}$ & $2.8 \mathrm{a}$ & $3.6 \mathrm{a}$ & $4.1 \mathrm{a}$ & $1.9 \mathrm{a}$ & $4.3 \mathrm{~b}$ & $17.8 \mathrm{a}$ \\
\hline Bayview & $0.0 \mathrm{a}$ & $0.0 \mathrm{c}$ & $0.0 \mathrm{c}$ & $0.0 \mathrm{c}$ & $0.1 \mathrm{~b}$ & $0.0 \mathrm{~b}$ & $0.2 \mathrm{c}$ & $0.3 \mathrm{~b}$ \\
\hline \multicolumn{9}{|l|}{ Year } \\
\hline 1998 & $0.0 \mathrm{~b}$ & $0.2 \mathrm{~b}$ & $0.7 \mathrm{~b}$ & $1.4 \mathrm{a}$ & $2.6 \mathrm{a}$ & $1.2 \mathrm{a}$ & $3.3 \mathrm{~b}$ & $9.4 \mathrm{~b}$ \\
\hline 1999 & $0.1 \mathrm{a}$ & $1.1 \mathrm{a}$ & $1.8 \mathrm{a}$ & $1.8 \mathrm{a}$ & $2.8 \mathrm{a}$ & $1.5 \mathrm{a}$ & $6.1 \mathrm{a}$ & $15.0 \mathrm{a}$ \\
\hline \multicolumn{9}{|c|}{ Lightly sheepnosed (Equatorial : Polar diameter $=1.05)$} \\
\hline Location & & & & & & & & \\
\hline Weslaco & $0.1 \mathrm{~b}$ & $1.7 \mathrm{~b}$ & $1.8 \mathrm{~b}$ & $4.0 \mathrm{a}$ & $5.8 \mathrm{a}$ & $2.7 \mathrm{a}$ & $4.3 \mathrm{a}$ & $20.4 \mathrm{~b}$ \\
\hline Mission & $0.7 \mathrm{a}$ & $4.6 \mathrm{a}$ & $5.1 \mathrm{a}$ & $4.4 \mathrm{a}$ & $5.1 \mathrm{a}$ & $2.2 \mathrm{a}$ & $4.3 \mathrm{a}$ & $26.3 \mathrm{a}$ \\
\hline Bayview & $0.1 \mathrm{~b}$ & $0.7 \mathrm{~b}$ & $0.6 \mathrm{c}$ & $0.3 \mathrm{~b}$ & $0.5 \mathrm{~b}$ & $0.5 \mathrm{~b}$ & $1.1 \mathrm{~b}$ & $3.8 \mathrm{c}$ \\
\hline \multicolumn{9}{|l|}{ Year } \\
\hline 1998 & $0.2 \mathrm{~b}$ & $1.6 \mathrm{~b}$ & $2.4 \mathrm{a}$ & $3.4 \mathrm{a}$ & $5.3 \mathrm{a}$ & $2.2 \mathrm{a}$ & $3.7 \mathrm{a}$ & $18.7 \mathrm{a}$ \\
\hline 1999 & $0.5 \mathrm{a}$ & $3.1 \mathrm{a}$ & $2.7 \mathrm{a}$ & $2.5 \mathrm{~b}$ & $2.3 \mathrm{~b}$ & $1.3 \mathrm{~b}$ & $2.8 \mathrm{a}$ & $14.9 \mathrm{~b}$ \\
\hline \multicolumn{9}{|c|}{ Normal (Equatorial $:$ Polar diameter $=1.00)$} \\
\hline Location & & & & & & & & \\
\hline Weslaco & $1.3 \mathrm{c}$ & $7.0 \mathrm{c}$ & $8.4 \mathrm{~b}$ & $7.5 \mathrm{~b}$ & $8.8 \mathrm{~b}$ & $2.2 \mathrm{~b}$ & $2.2 \mathrm{~b}$ & $37.3 \mathrm{c}$ \\
\hline Mission & $4.8 \mathrm{~b}$ & $13.5 \mathrm{~b}$ & $8.4 \mathrm{~b}$ & $6.0 \mathrm{~b}$ & $5.0 \mathrm{c}$ & $1.8 \mathrm{~b}$ & $3.2 \mathrm{~b}$ & $42.7 \mathrm{~b}$ \\
\hline Bayview & $8.7 \mathrm{a}$ & $27.4 \mathrm{a}$ & $18.1 \mathrm{a}$ & $13.4 \mathrm{a}$ & $14.8 \mathrm{a}$ & $6.6 \mathrm{a}$ & $6.8 \mathrm{a}$ & $96.0 \mathrm{a}$ \\
\hline \multicolumn{9}{|l|}{ Year } \\
\hline 1998 & $6.1 \mathrm{a}$ & $19.8 \mathrm{a}$ & $14.0 \mathrm{a}$ & $9.1 \mathrm{a}$ & $9.2 \mathrm{a}$ & $2.4 \mathrm{~b}$ & $3.4 \mathrm{a}$ & $64.1 \mathrm{a}$ \\
\hline 1999 & $3.7 \mathrm{~b}$ & $12.0 \mathrm{~b}$ & $9.2 \mathrm{~b}$ & $8.9 \mathrm{a}$ & $9.9 \mathrm{a}$ & $4.7 \mathrm{a}$ & $4.6 \mathrm{a}$ & $53.2 \mathrm{~b}$ \\
\hline
\end{tabular}

${ }^{2}$ Values are means for 60 or 90 trees for each location or year, respectively.

${ }^{y}$ Mean separation within columns and categories by LSD, $P \leq 0.05$. yield ( $\mathrm{kg} /$ tree) in all locations were higher in 1999 than in 1998. Combining both years, mean yield in Mission was the highest $(147 \mathrm{~kg} /$ tree) followed by Bayview (121 kg/tree) and Weslaco $(60 \mathrm{~kg} / \mathrm{tree})$. Previous experiments (Cohen et al., 1972; Reuther 1973; Wutscher, 1976) and our results suggest that humidity and temperature may play a major role in inducing sheepnosing. Furthermore, future studies on sheepnosing should include weather data.

Large fruit is more likely to be sheepnosed than is small fruit (Sauls, 1998). A strong relationship exists between peel growth and endogenous hormonal balance (Goren and Monselise, 1965), and excessive cell division and cell elongation are strongly correlated with rough peel (Erner et al., 1975). The thicker higher content of gibberellins and cytokinins, which, in turn, may increase transport of photosynthates into the fruit (Erner et al., 1976). The percentages of sheepnosed fruits were greater among the larger $(32,36$, and 40$)$ than among the smaller fruits (48 and 56) (Table 1).

Rootstock effects. In 1999, trees grown on 'Carrizo' rootstock produced significantly greater percentages of severely sheepnosed fruit $(25.8 \%)$ than did those on 'Swingle' $(10.2 \%)$ rootstock (Table 3). The significant rootstock $\times$ year interaction reflected the greater rootstock effects observed in 1999 when peel in large fruit could be attributed to a 
sheepnosing was more severe. For example, greater differences were recorded in the severely and moderately sheepnosed fruit in 1998 than in 1999.

Irrigation method. Flood-irrigated trees on sour orange had a significantly higher percentage of sheepnosed fruits than did those that were irrigated by microjet (Table 4). The percentages of sheepnosed fruit in all categories were significantly affected by year. These results suggest that microjet irrigation may contribute to a higher percentage of sheepnosed fruit by not providing sufficient water, which agrees with the results of Cohen et al. (1968).
Rind thickness and fruit size can be affected by water stress (Levy et al., 1979). Since no local studies were conducted to determine scheduling for optimal microjet irrigation, our experimental field irrigation scheduling was based on $25 \%$ soil water depletion in the $122-\mathrm{mm}$ (4-ft.) deep rooting zone, and on canopy diameter. Although rainfall was accounted for in overall water budget, very little information is available about the proportion of water being extracted by the trees from irrigated and nonirrigated zones following rains (D. Swietlik, personal communication). Microjet irrigation saves water, minimizes weed growth, is useful for fertilizer application, and may produce higher yields; however, without proper management and optimal timing, it may not provide sufficient water for normal peel and pulp development. Further studies are needed before any conclusions are drawn on the effect of irrigation on sheepnosing.

Effects on juice percentage and fruit quality. Percentage of juice was significantly lower in severely sheepnosed fruit than in normal fruit (Table 5), in agreement with the general obervation that large fruits have a higher percentage of peel and less juice (Cruse et al., 1982). Peel thickness was progressively greater

Table 2. Location and year effects on the percentage of sheepnosed and normal fruit of all sizes of 'Rio Red' grapefruit. ${ }^{\text {' }}$

\begin{tabular}{|c|c|c|c|c|c|c|c|c|c|c|c|c|}
\hline & \multicolumn{12}{|c|}{ Severity of sheepnosing } \\
\hline & \multicolumn{3}{|c|}{ Severe } & \multicolumn{3}{|c|}{ Moderate } & \multicolumn{3}{|c|}{ Light } & \multicolumn{3}{|c|}{ None } \\
\hline & 1998 & 1999 & Mean & 1998 & 1999 & Mean & 1998 & 1999 & Mean & 1998 & 1999 & Mean \\
\hline \multicolumn{13}{|l|}{ Location } \\
\hline Weslaco & 0.0 & 47.5 & $23.8 \mathrm{c}^{\mathrm{y}}$ & 6.9 & 30.1 & $18.5 \mathrm{~b}$ & 23.9 & 16.9 & $20.4 \mathrm{~b}$ & 69.1 & 5.5 & $37.3 \mathrm{a}$ \\
\hline Mission & 23.5 & 2.9 & $13.2 \mathrm{~b}$ & 20.9 & 14.8 & $17.8 \mathrm{~b}$ & 27.8 & 24.8 & $26.3 \mathrm{c}$ & 27.9 & 57.5 & $42.7 \mathrm{~b}$ \\
\hline Bayview & 0.0 & 0.0 & $0.0 \mathrm{c}$ & 0.3 & 0.3 & $0.3 \mathrm{a}$ & 4.3 & 3.1 & $3.8 \mathrm{a}$ & 95.4 & 96.6 & $96.0 \mathrm{c}$ \\
\hline Mean & 7.8 & $16.8^{*}$ & & 9.4 & $15.0^{*}$ & & 18.7 & $14.9^{*}$ & & 64.1 & $53.2^{*}$ & \\
\hline \multicolumn{13}{|l|}{ Significance } \\
\hline Location (L) & & $*$ & & & $*$ & & & $*$ & & & $*$ & \\
\hline Year $(\mathrm{Y})$ & & $*$ & & & $*$ & & & $*$ & & & $*$ & \\
\hline $\mathrm{L} \times \mathrm{Y}$ & & $*$ & & & $*$ & & & NS & & & $*$ & \\
\hline
\end{tabular}

${ }^{{ }^{2}}$ Values are means for 60 or 90 trees for each location or year, respectively.

${ }^{y}$ Mean separation within columns and categories by LSD, $P<0.05$.

Ns, ${ }^{*}$ Nonsignificant or significant at $P \leq 0.01$.

Table 3. Rootstock and year effects on the percentage of different categories of sheepnosed and normal fruit in 'Rio Red' grapefruit of all $\operatorname{sizes}^{z}$ at Texas A\&M Univ.-Kingsville Citrus Center West Farm for 2 years.

\begin{tabular}{|c|c|c|c|c|c|c|c|c|c|c|c|c|}
\hline & \multicolumn{12}{|c|}{ Severity of sheepnosing } \\
\hline & \multicolumn{3}{|c|}{ Severe } & \multicolumn{3}{|c|}{ Moderate } & \multicolumn{3}{|c|}{ Light } & \multicolumn{3}{|c|}{ None } \\
\hline & 1998 & 1999 & Mean & 1998 & 1999 & Mean & 1998 & 1999 & Mean & 1998 & 1999 & Mean \\
\hline \multicolumn{13}{|l|}{ Rootstock } \\
\hline Carrizo & 1.2 & 47.4 & $25.8 \mathrm{a}^{\mathrm{y}}$ & 4.5 & 28.3 & $17.2 \mathrm{a}$ & 19.2 & 14.1 & $16.5 \mathrm{ab}$ & 75.2 & 10.2 & $40.5 \mathrm{a}$ \\
\hline Troyer & 0.9 & 44.1 & $22.5 \mathrm{ab}$ & 2.8 & 28.8 & $15.7 \mathrm{a}$ & 15.0 & 15.6 & $15.2 \mathrm{a}$ & 81.4 & 11.6 & $46.6 \mathrm{a}$ \\
\hline Sour orange & 1.4 & 32.9 & $17.2 \mathrm{~b}$ & 6.1 & 33.3 & $19.7 \mathrm{a}$ & 22.0 & 18.1 & $20.1 \mathrm{~b}$ & 70.5 & 15.7 & $43.1 \mathrm{a}$ \\
\hline Chinese & 1.0 & 42.9 & $22.0 \mathrm{ab}$ & 4.0 & 32.1 & $18.1 \mathrm{a}$ & 15.6 & 15.6 & $15.7 \mathrm{a}$ & 79.3 & 9.4 & $44.1 \mathrm{a}$ \\
\hline Swingle & 0.2 & 20.1 & $10.2 \mathrm{c}$ & 4.9 & 27.9 & $16.4 \mathrm{a}$ & 19.0 & 27.4 & $23.2 \mathrm{~b}$ & 76.0 & 24.6 & $50.3 \mathrm{~b}$ \\
\hline Mean & 0.9 & $37.5^{*}$ & & 4.4 & $30.1^{*}$ & & 18.0 & 18.2 & & & 76.7 & $14.3^{*}$ \\
\hline \multicolumn{13}{|l|}{ Significance } \\
\hline Rootstock (R) & & * & & & NS & & & $*$ & & & ** & \\
\hline Year $(\mathrm{Y})$ & & * & & & $*$ & & & NS & & & $*$ & \\
\hline $\mathrm{R} \times \mathrm{Y}$ & & * & & & NS & & & $*$ & & & * & \\
\hline
\end{tabular}

${ }^{2}$ Values are means for 60 or 150 trees for each rootstock or year, respectively.

${ }^{y}$ Mean separation within columns and categories by LSD, $P \leq 0.05$.

Ns, ${ }^{*}, * *$ Nonsignificant or significant at $P \leq 0.01$ or 0.05 , respectively.

Table 4. Irrigation and year effects on the percentage of sheepnosed and normal fruit of all sizes 'Rio Red' grapefruits of all sizes for two years ${ }^{2}$.

\begin{tabular}{|c|c|c|c|c|c|c|c|c|c|c|c|c|}
\hline & \multicolumn{12}{|c|}{ Severity of sheepnosing } \\
\hline & \multicolumn{3}{|c|}{ Severe } & \multicolumn{3}{|c|}{ Moderate } & \multicolumn{3}{|c|}{ Light } & \multicolumn{3}{|c|}{ None } \\
\hline & 1998 & 1999 & Mean & 1998 & 1999 & Mean & 1998 & 1999 & Mean & 1998 & 1999 & Mean \\
\hline \multicolumn{13}{|l|}{ Irrigation } \\
\hline Microjet & 0.1 & 22.5 & $11.3 \mathrm{a}^{\mathrm{y}}$ & 3.2 & 39.1 & $21.1 \mathrm{a}$ & 17.9 & 23.9 & $20.9 \mathrm{a}$ & 78.8 & 14.4 & $46.6 \mathrm{a}$ \\
\hline Flood & 0.3 & 14.9 & $7.6 \mathrm{a}$ & 0.2 & 33.0 & $16.6 \mathrm{~b}$ & 8.8 & 28.1 & $18.5 \mathrm{a}$ & 90.7 & 24.0 & $57.3 \mathrm{~b}$ \\
\hline Mean & 0.2 & $18.7^{*}$ & & 1.7 & $36.1^{*}$ & & 13.4 & $26.0^{*}$ & & 84.7 & $19.2^{*}$ & \\
\hline \multicolumn{13}{|l|}{ Significance } \\
\hline Irrigation (I) & & NS & & & $* *$ & & & NS & & & ** & \\
\hline Year $(\mathrm{Y})$ & & $*$ & & & $*$ & & & $*$ & & & $*$ & \\
\hline $\mathrm{I} \times \mathrm{Y}$ & & NS & & & NS & & & NS & & & NS & \\
\hline
\end{tabular}

${ }^{2}$ Values are means for 60 trees for both each irrigation method and year.

${ }^{\mathrm{y}}$ Mean separation within columns and categories by LSD, $P \leq 0.05$.

Ns, *, ** Nonsignificant or significant at $P \leq 0.01$ or 0.05 , respectively. 
Table 5. Comparison of fruit quality ${ }^{z}$ of sheepnosed vs. normal 'Rio Red' grapefruit. ${ }^{y}$

\begin{tabular}{lccccccrr}
\hline \hline & TA & SSC & SSC : TA ratio & PJ & Fruit wt (g) & Thickness $(\mathrm{mm})$ & Firmness (N) & E : P ratio \\
\hline Category & & & & & & & & \\
Normal & $1.18 \mathrm{a}^{\mathrm{x}}$ & $9.91 \mathrm{a}$ & $8.43 \mathrm{~b}$ & $57.4 \mathrm{a}$ & $477 \mathrm{c}$ & $5.56 \mathrm{a}$ & $26.7 \mathrm{c}$ & $1.00 \mathrm{c}$ \\
Moderate & $1.14 \mathrm{ab}$ & $9.75 \mathrm{a}$ & $8.62 \mathrm{ab}$ & $53.8 \mathrm{~b}$ & $580 \mathrm{~b}$ & $7.49 \mathrm{~b}$ & $29.4 \mathrm{a}$ & $1.09 \mathrm{~b}$ \\
Severe & $1.11 \mathrm{~b}$ & $9.66 \mathrm{a}$ & $8.80 \mathrm{a}$ & $50.2 \mathrm{c}$ & $663 \mathrm{a}$ & $9.82 \mathrm{c}$ & $28.1 \mathrm{~b}$ & $1.15 \mathrm{a}$ \\
Year & & & & & & & & \\
1998 & $1.11 \mathrm{~b}$ & $10.09 \mathrm{a}$ & $9.11 \mathrm{a}$ & $54.7 \mathrm{a}$ & $566 \mathrm{~b}$ & $7.61 \mathrm{a}$ & $32.9 \mathrm{a}$ & $1.03 \mathrm{~b}$ \\
1999 & $1.25 \mathrm{a}$ & $8.72 \mathrm{~b}$ & $6.97 \mathrm{~b}$ & $51.0 \mathrm{a}$ & $606 \mathrm{a}$ & $7.86 \mathrm{a}$ & $12.5 \mathrm{~b}$ & $1.05 \mathrm{a}$ \\
\hline
\end{tabular}

${ }^{2} \mathrm{SSC}=$ soluble solids concentration; $\mathrm{TA}=$ titratable acidity; $\mathrm{PJ}=$ percentage of juice; $\mathrm{E}: \mathrm{P}$ ratio $=$ Equatorial $:$ Polar diameter

${ }^{y}$ Values are means for 60 or 90 fruits for each category or year, respectively.

${ }^{x}$ Mean separation within columns and categories by LSD, $P \leq 0.05$.

in severely sheepnosed than in moderately sheepnosed or normal fruit (Table 5). Severely sheepnosed fruit had a higher soluble solids : titratable acidity ratio than did normal fruit because of their lower acid level.

While significant, the effects of irrigation and rootstock appear not to have as large an effect on sheepnosing as do location and year. A higher percentage of normal fruits were produced in 1998 than in 1999 in all three experiments. This suggests that weather conditions may alter hormonal balance, thereby inducing sheepnosing. Future studies at the physiological basis of sheepnosing may be directed toward the effects of climatic conditions on hormonal imbalances. The critical growth stage at which sheepnosing is initiated should also be determined.

\section{Literature Cited}

Cohen, A., A. Goell, A. Rassis, and M. Gokkes 1968. Effects of irrigation regimes on grapefruit peel and pulp relationships. Israel J. Agr. Res. 18:155-160.
Cohen, A., J. Lomas, and A. Rassis. 1972. Climatic effects on fruit shape and peel thickness in 'Marsh Seedless' grapefruit. J. Amer. Soc. Hort. Sci. 97:768-771.

Cruse, R.R., C.L. Wiegand, and W.A. Swanson. 1982. The effect of rainfall and irrigation management on citrus juice quality in Texas. $\mathrm{J}$. Amer. Soc. Hort. Sci. 107:767-770.

Erner, Y., R. Goren, and S.P. Monselise. 1976. The rough fruit condition of the Shamouti orange: Connections with the endogenous hormonal balance. J. Hort Sci. 51:367-374.

Erner, Y., S.P. Monselise, and R. Goren. 1975. Rough fruit condition of the Shamouti orange: Occurrence and patterns of development. Physiol. Veg. 13:435-443.

Gibson, A.C. 1975. Developmental studies of pyriform fruits of grapefruit. J. Amer. Soc. Hort. Sci. 100:674-678.

Gilfillan, I.M. and J.A. Stevenson. 1976. Sheepnose and leaf nutrient status in grapefruit. Citrus Subtrop. Fruit J. 514:5-7.

Goren, R. and S.P. Monselise. 1965. Interelation of hesperidin, some other natural components and certain enzyme systems in developing Shamouti orange fruits. J. Hort. Sci. 40:83-99.

Levy, Y., J. Shalhevet, and H. Bielorai. 1979. Effect of irrigation regime and water salinity on grapefruit quality. J. Amer. Soc. Hort. Sci. 104:356359.

Nauer, E.M., J.H. Goodale, L.L. Summers, and W. Reuther. 1975. Climatic effects on grapefruit and lemons. Calif. Agr. 29(3):8-10.

Reuther, W. 1973. Climate and citrus behavior, p. 280-337, 498-499. In: Walter Reuther (ed.). The citrus industry. vol. III. Agr. Publ. Univ. Calif., Berkeley.

Sauls, J.W. 1998. Comparisions of fruit shape of 'Rio Red' and 'Henderson' grapefruit, Citrus paradisi Macf., in Texas. Subtrop. Plant Sci. 50:15-19.

Shellie, K.C., M.J. Firko, and R.L. Mangan. 1993. Phytotoxic response of 'Dancy' tangerine to high-temperature, moist, forced-air treatment for fruit fly disinfestation. J. Amer. Soc. Hort. Sci. 118:481-485.

Soost, R.K., J.W. Cameron, R.H. Burnett, and B. England. 1965. Fruit characters of nucellar Washington Navel orange and Marsh grapefruit budlines. Calif. Citrograph 51(1):324.

Wutscher, H.K. 1976. Influence of night temperature and daylength on fruit shape of grapefruit. J. Amer. Soc. Hort. Sci. 101:573-575. 